\title{
The Relative Importance of Internal Factors for Bank Performance in Developed and Emerging Economies
}

\author{
Olga Uzhegova
}

\author{
Department of Finance and Accounting, Bang College of Business, KIMEP University, Almaty, Kazakhstan
}

\section{Doi:10.5901/mjss.2015.v6n3p277}

\section{Abstract}

This study empirically explored the relative importance of bank-specific factors on the profitability of banks operating in developed, advanced emerging, secondary emerging and frontier markets (based on the FTSE Group's classification) from 2002 to 2008. The sample consisted of 6,926 banks in developed countries, 556 banks in advanced emerging countries, 2,103 banks in secondary emerging countries, and 563 banks in frontier markets. As a result of this study, employing multivariate analysis of covariance (MANCOVA), empirical support was provided for the theoretical proposition pursuant to which the importance of bank-specific factors goes countercyclically with the business cycle. This can be explained by a reduction in agency problems and by the convergence of expectations of all market participants with respect to the overall economic situation in the periods of high economic growth. In contrast, in periods of financial distress, the level of uncertainty increases sharply, which leads to a substantial squeezing in profit margins.

Keywords: bank performance, profitability, bank-specific factors, emerging markets, developed economies, economic growth, CAMEL, capital, liquidity, operational efficiency, earning ability, risk, MANCOVA

\section{Introduction}

The main purpose of this study is to examine the effect of bank-specific (internal) factors on performance of banks operating in economies characterized by different levels of regulatory, financial system, and economic development. The level of financial system, regulatory and economic development are mentioned together following the idea proposed by Levine (1997) and Rajan and Zingales (1998) pursuant to whom "a well-functioning financial system contributes to investment and growth" (Jonson, McMillan and Woodruff 2002, 1335) while strong regulatory basis along with high protection of investors' rights is essential for proper functioning of financial system and availability of external finance (La Porta et al. 1997).

This study argues that due to the global tendency towards the standardization of banking practices triggered by elaboration of the Basel requirements, the level of importance of internal factors for bank performance is mostly associated with the business cycle than with anything else. The effect of these factors is countercyclical to the level of economic activity due to divergence of expectations of market participants, an increase in agency problems and default rates in periods of economic downturn.

Based on the foregoing the theoretical proposition that the relative importance of bank-specific factors goes countercyclically with business cycle is to be tested.

Understanding of how bank performance is determined by internal factors contingent upon the stage of the economic activity in any market can serve as a guide for regulators concerning when any regulatory requirements should be imposed on banking organizations to ensure at least stability of the banking sector in particular and the whole economy in general.

\section{Literature Review}

The issues of the effect of capital adequacy, liquidity, and geographical/activity diversification on bank performance received the most attention in the literature.

Demirgüç-Kunt and Huizinga (1999), for instance, found a positive and significant impact of capital ratio (used as a proxy for capital adequacy) on the return on assets (ROA). This direct correlation is in line with other studies. A possible explanation is that "well capitalized banks face lower expected bankruptcy costs and thereby reduce their costs of funding" (Beckmann 2007, 6). 
In contrast, Goddard, Molyneux, and Wilson (2004) provided the theoretical reasoning for a negative capitalearnings relationship. Since banks with a high capital ratio are risk-averse, they "ignore potential [risky] investment opportunities" and, as a result, "investors demand a lower return on their capital in exchange for lower risk" (Beckmann 2007, 10).

Diamond and Rajan $(2000,2431)$ highlighted how the capital structure of banks affect their credit-creation and liquidity creation functions. In particular, banks provide liquidity to depositors upon their demand (on the liability side) and to "difficult, illiquid borrowers" on the asset side of the balance sheet), "thus enhancing the flow of credit in the economy" (Diamond and Rajan 2001, 287). They also noted that "deposits are fragile and prone to runs"(Diamond and Rajan 2000, 2431). As a result, illiquidity may be created by banks as a defense mechanism. The first natural response of banks which are subject to liquidity shortages is that they may ration financing, providing it only to good-quality borrowers (Webb 2000,69 ) which, overall, could negatively affect profits.

There is long history of debates about benefits and costs of activity and geographical diversification. One of the most common and most important benefits of diversification for banks is a lower cost of capital. Kotrozo and Choi (2006, 7) noted that because external capital is more costly than internal, well-diversified banking organizations can take advantage of transferring internal capital "from less efficient operations to areas where its use will be most beneficial to the organization." They also emphasized that the availability of internal capital may also alleviate underinvestment problems that could arise from foregoing good investment projects (if no internal financing is available) due to the asymmetry of information between the organization and investors. Kotrozo and Choi $(2006,7)$ noted that in diversified banking organizations either across activities or geography, employees have the opportunity "to apply their skills and abilities to other products, or can transfer knowledge to other locations to improve performance across the organization." In other words, economies of scope could be achieved through activity diversification and economies of scale could be achieved through geographical diversification. In both cases costs would be reduced substantially.

Deng and Elyasiani $(2008,1219)$, Lewellen (1971), and Boot and Schmeits (2000) stressed the importance of geographical diversification for diminishing earning volatility through the "coinsurance effect" by "spreading operations across areas with different economic environments" (Kotrozo and Choi 2006, 9).

The literature has also analyzed the effect of bank size on overall performance. Overall, the empirical results with respect to the impact of size on the profitability of banks are mixed. Banks can benefit from a size effect through achieving economies of scale or through being perceived as more competitive internationally. The latter goes back to the issue of to the community's trust of large organizations. At the same time, there is empirical evidence that larger banks are less efficient (Fries, Neven, and Seabright 2002, 21-23).

Even though the direction of the association between different factors and bank profitability received great attention in the literature, this issue is not the focus of this study.

\section{Materials and Methods}

To achieve the purpose of this study:

1. A set of bank-specific variables will be defined to be included into the analysis based on the literature review and sound judgment.

2. In order to test this study's hypotheses, all banks will be divided into four different groups based on the type of market in which every bank operates following FTSE Group classification;

3. All tests will be conducted on an annual basis;

4. Along with all tests, the results of the descriptive statistics for all variables will be provided.

This study will proceed by providing the rationale for choosing the bank-specific factors evaluated herein.

The choice of bank-specific factors is driven primarily by the CAMEL rating system (whereas $C$ stands for capital adequacy, A- assets quality, M - management quality, E - earning ability, and L- liquidity) developed by the US Federal Deposit Insurance Corporation (FDIC) for "early identification of problems in banks' operations" (Hunjak and Jakovčević $2001,150)$ and which is used by many banking analysts in analyzing the performance of banks (Balteş and Rodean 2014, 134).

Capital Adequacy. The ratio of equity to earning assets (ETEA) as a proxy for "the equity cushion available to absorb losses on the loan book" (Bankscope) will be used in this study to assess the effect of level of capital adequacy on bank performance. A high ratio will reflect more protection for banks, which will influence the overall stability of banks.

In periods of high economic activity, the probability of default on the part of the real sector (clients of banks) is lower, and the effect of the level of bank's capitalization on banks' profitability (with respect to expected bankruptcy costs) should be less pronounced. In contrast, in periods of economic downturn, banks have to be ready for to absorb losses on 
the loan book, which come from higher default rates of the real sector than in periods of economic growth. Therefore, this study argues that the importance of total capital base for banks' profitability goes countercyclically to the business cycle.

Asset Quality. This study will employ the ratio of Loan Loss Provisions to Net Interest Revenue (LLP_NIR) as a proxy for asset quality. This is a measure of how risk is remunerated by margins (here "margins" refer to net interest revenue). Thus, in well-run banks this ratio is low. The lower this ratio, the better. The deterioration of this ratio means that the increase in risk is not remunerated by higher margins.

Insofar as during the periods of high economic activity borrowers are less likely to default on their obligations there is less attention paid to them than in periods of financial distress which results in a decrease in consideration of the level of loan loss provisions in the periods of economic growth.

Management Quality. Duygun-Fethi and Pasiouras (2009) reported that indicators of management quality in CAMEL are rarely used in empirical studies due to difficulties associated with the proper assessment of management quality. In essence, the assessment of management quality is aimed at the determination of the capability of banks' management "to identify, measure, monitor, and control the risks of an institution's activities and to ensure a financial institution's safe, sound, and efficient operation in compliance with applicable laws and regulations" (Federal Register 1997, 755).

Based on the foregoing, management quality in banking organizations could be gauged based on risk management expertise, operational efficiency, and the ability to get relatively cheap financing and sell banking products. In fact, these elements form the core business of banking organizations.

The risk management is a cornerstone for the success of any financial intermediary due to high risk exposure, while the inability to "identify, measure, monitor, and control the risks of an institution's activities" will lead to bank's default. The ratio of Impaired Loans to Gross Loans (ILGL) will be used in this study as a proxy for the quality of risk management. As the value of this ratio tends towards zero, the higher is the level of risk management expertise of the bank. Theoretically, this ratio could be equal to zero. However, this does not mean that a bank takes no risk, because no one bank can avoid risk once it has provided financing to any entity or individual. Instead, it will indicate very strong risk management in place.

A cost to income ratio (CIR) will be used as a measure of operational efficiency (as a second component of management quality). This ratio measures "the overheads or costs of running the bank, the major element of which is normally salaries, as percentage of income generated before provisions" (BankScope Database 2009).

The difference between the ratio of interest income to total customer loans and ratio of interest expense to total funding (hereinafter Spread) will be used as the proxy for ability of banks to run their core business (as a third component of management quality).

$\frac{\text { Interest_Income }}{\text { Total_Customer_Loans }}-\frac{\text { Interest_Expenses }}{\text { Total_Funding }}=$ Spread

where

Interest expenses - interest that the bank pays on its own loans;

Total Funding $=$ Total Deposits

+ Total Money Market Funding

+ Total Other Funding

Due to the intensive global integration of financial markets, there was a tremendous process of knowledge sharing. This should serve as a trigger factor for the improvement of the risk management expertise of banks across-the-board. The period covered in this study includes periods of economic growth and economic recession. Thus, how the performance of banks has been affected by changes in risk management expertise of banks contingent upon the stage of economic development can be explored. This study argues that the level of risk management expertise per se is not able to explain the performance of banks, due to banks' high level of dependence on the real sector. In particular, any improvement in banks' performance, if it is associated with improvement of risk management, should have a strong economic foundation. In essence, in periods of economic recession when default rates in the real sector become higher than in the periods of economic growth, in order to rescue a bank, special attention should be paid to the risk management practices in place and, probably, they should be reviewed. Therefore, this study hypothesizes that the importance of the level of risk management expertise in periods of economic recession is higher than in periods of economic growth.

In periods of high economic activity, there is a process of expansion of the real sector. As a result, there is also an increase in the number of market participants and banks' clients. Due to this, banks experience a substantial increase in total revenues (and, therefore, an increase in income generated before provisions) during periods of high economic growth, while the increase in overheads is increasing at a decreasing rate in comparison with the increase in total 
revenues. Thus, in periods of high economic growth, the decrease in the cost to income ratio does not necessarily reflect improvements in the operational efficiency of banks. In turn, in periods of economic distress, the gap between total revenues and overheads is diminishing. Due to this, the importance of cost to income ratio as a measure of banks' operational efficiency should be higher during periods of financial distress.

With respect to the third component of management quality explored in this study, namely spread, this study argues that during periods of economic downturn, earning a spread sufficient enough to survive for banks becomes a crucial issue. This is due to a deterioration of the risk profiles of banks in periods of economic recession, which leads to an increase in the costs of financing banks' activities from a shrinking of the real sector that makes the selling of banking products more difficult. Therefore, the importance of running the core business of banks is to be inflated in periods of economic slowdown.

Earning Ability. As a proxy for the earning ability of banks, this study will use the ratio of post-tax profit to total share capital. Here, total share capital includes issued and fully paid common and preferred shares. The rationale for including the ratio of post-tax profits to total share capital in this analysis as an independent variable (while it is in nature a profitability ratio that indicates a return on shareholding capital) is as follows.

In assessing the earning ability of banks, the sources and quality of earnings along with the "ability to provide for an adequate capital through retained earnings" are assessed (Federal Register, 1997). In the normal course of economic activity, banks generally have three main sources of funding available: retained earnings, debt instruments and equity. In contrast, in periods of economic downturn, after retained earnings vanish and debt financing becomes unavailable due to a dramatic deterioration of the risk profiles of banks, the only source of funding in adverse circumstances is the issuance of common and preferred shares.

A bank's capacity to generate a higher level of post-tax profits on equity provides profound insight into its performance. It is due to the fact that in financial distress, while all financial intermediaries have lower credibility and some even do not have access to borrowing, the issue of equity is very likely to be effectuated with a substantial discount, since no investor is willing to become a shareholder (and being paid last in worst case scenarios since government and debt-holders have priority) of a doubtful business entity, unless he gets high premium. This is especially true for less developed countries with a higher level of divergence of expectations among market participants and bigger agency problems and where the financial system is characterized by a lower level of regulation which, in turn, indicates that the protection of investors' rights is desired to leave much better. "Going concern" status is carefully assessed by the market and a bank faces three alternative scenarios:

- Raising equity capital without a discount for shares $\rightarrow$ few shares give good financing (rare);

- Raising equity capital with a discount for shares $\rightarrow$ substantial number of shares needed for even modest funds;

- The issuance of heavily discounted stock $\rightarrow$ an extreme case of a large stock exchange for small amount of funds.

These three scenarios demonstrate that a decent level of the ratio of post-tax profits to total share capital is less likely to result from operating revenues (highly profitable deals or something like this), but instead from maintaining the same level of equity - not being squeezed out from over-suspicious, in crisis times, debt capital markets (for such reasons as a having risky portfolio). The key to staying a good bank in the inter-bank borrowing market is to have customers that are companies working in real sector (in this section, the "real sector" means companies focused on metals and mining, car manufacturing, chemical industry, agriculture) that are less subject to fluctuations (they generate more or less stable net cash flows), making the owner of such a portfolio a reliable counterparty.

In a distressed economic environment, very few banks make extraordinary profits. Therefore, when after-tax profit is not significantly increasing, the ratio of after-tax profit to total share capital can be improved almost exclusively via the stability of the amount of equity in the denominator. The maintenance of a stable level of equity demonstrates that the bank has good financials, enabling it to raise money through borrowing and not resorting to increasing equity. The evaluation of a bank's eligibility for borrowing by financial markets is based on good-quality assets and performance. In a situation where one bank has customers in the real sector and another bank mainly tokes risks by providing loans to customers with a lot of intangible assets on their balance sheet (internet companies, technological start-ups, R\&D boutiques), financial markets favor the first-type of banks, since, as the history of last decades shows, the cash flows and assets of the "real sector" are much more stable and substantial.

Thus, if financial markets like the $1^{\text {st }}$ type of banks, they will give them more debt, if needed, and the equity of such favored banks remains at the same level. Since there are only two ways that the ratio of post-tax profits to total share capital could be changed (these are either through changes in post-tax-profits or in equity), ensuring that the denominator (total share capital) is not growing is $50 \%$ of the solution to making sure that the overall ratio of post-tax profits to total 
share capital is at decent a level.

This demonstrates that banks with conservative policies will have a better ratio of post-tax profits to total share capital. This is mainly due to remaining with the real sector, as well as the ability to avoid the pitfall of being allured by some high growing intangible-based businesses (e.g. tech and dot com).

Paying attention to changes in this ratio may, in fact, give a stimulus to the market to abstain from any further deals with such a bank. Hence, the ratio of post-tax profits to total share capital should act as one of the most appropriate variables for defining which banks are in more trouble.

Based on the foregoing discussion, this study argues that the ability of banks to earn profits (as a return on share capital) and to maintain the ratio of post-tax-profits to total share capital at decent level is crucial for banks in the periods of financial distress.

Liquidity. One of the heavily discussed causes of financial crises where banks play central role is the inability of banks to cope with liquidity shortages. Pursuant to Diamond and Rajan's (2005) bank failures are contagious and are caused by liquidity problems arising from "delays in the generation of project cash flows by borrowers" or from the "earlier termination of projects." In essence, their argument is that liquidity shortages can come from the asset side rather than from the liability side. Given that aggregate delays in the "generation of project cash flows by borrowers," which leads to the creation of an aggregate real liquidity shortage, is inherent in the real sector during periods of economic downturn, the ability of banks to cope with such liquidity shortages becomes highly important. This is in line with the idea of Bronfenbrenner $(1945,424)$, who stated that "an increase in real income ... would be expected ... to decrease the importance of liquidity." Thus, in periods of economic growth characterized by an increase in real income, the real sector is not supposed to generate real liquidity shortages which negatively affect the liquidity of banks and as a result their profitability.

The ratio of net loans to total assets will be used as a proxy for the liquidity of banks. This ratio indicates what percentage of the bank's assets is tied up in loans. The lower this ratio is, the more liquid the bank is (BankScope Database, 2009).

In addition to that, this study considers the importance of diversification and the size of banks for banks' profitability.

Diversification. This study will explore how both income and geographical diversification affect the profitability of banks operating in countries with different levels of financial system development at different stages of business cycle.

To define the level of income diversification, following Kotrozo and Choi's 2006 study, the Herfindahl-Hirschman Index $(\mathrm{HHI})$ will be computed in the following way:

$H H I_{\text {Income }}=(\text { Interest Income/Total Operating Income })^{2}$

+ (Commission Income/Total Operating Income $)^{2}$

+ (Fee Income/Total Operating Income $)^{2}$

+ (Trading Income/Total Operating Income $)^{2}$

+ (Non-Interest Income/Total Operating Income $)^{2}$

+ (Other Operating Income/Total Operating Income) ${ }^{2}$

Herfindahl-Hirschman Index can take value from 0.17 to 1 whereas:

- "1" indicates that a bank is not involved in income diversification, since its income is concentrated in one activity; and

- "0.17" indicates that the bank's income is highly diversified, since it is uniformly distributed over all activities (As long as bank will earn its income in at least one of six activities listed the lowest possible value is $6 \times(1 / 6) 2=0.16(6) \approx 0.17)$.

With respect to geographical diversification, first- and second-type geographical diversification will be incorporated into the model by the means of including dummy variables ("1" - bank is diversified; "0" - bank is not diversified).

A bank is viewed as diversified geographically based on the first-type geographical diversification if it is represented in at least one foreign country.

A bank is viewed as diversified geographically based on the second-type geographical diversification if its main domestic country differs from where a bank operates.

Given that income from non-interest activities is not correlated (at least not perfectly correlated) with income from lending activities, activity diversification "gives rise to a more stable stream of profits" (Chiorazzo, Milani, and Salvini 2008). As long as the volatility of earnings increases in periods of financial distress, the importance of income diversification is supposed to be more pronounced in such times rather than in periods of economic growth.

In terms of geographical diversification, this study focuses on the issue of opening up domestic markets to foreign banks. The research interest of this study is driven by the fact that the opening of a domestic market to the participation of 
foreign banks triggers the process of integrating these countries into the global financial system. The opening of domestic markets allows for the further development of the domestic banking industry by bringing knowledge and technologies. This means that banks' main domestic countries, which are characterized by a higher level of financial system development, can have superior knowledge of how a bank should operate, especially with respect to risk management. Dages, Goldberg, and Kinney $(2000,19)$ noted that because of their superior knowledge and technology, such banks are able to catch clients from the most profitable businesses with the best risk profiles in the markets which they penetrated. Because of this, this study supposes that the impact of second-type geographical diversification should be more pronounced for the profitability of banks operating in less developed countries where the process of opening the domestic market to participation of foreign bank is a relatively recent phenomenon. Further, this effect becomes more important with a decrease in the level of economic activity. This is mainly due to the availability of internal capital (to be provided by the parent company) and human resources whose skills and abilities could be directed from parent companies to support the operations of banks following the second-type diversification in difficult times.

With respect to the first-type geographical diversification, it is expected that the importance of this factor is also more pronounced during periods of financial distress. This is due to the availability of internal capital that could be transferred from less efficient operations to more efficient ones, which is vital in periods of economic downturn.

Size of the Bank. The main concern of this study is to explore the extent to which banks' size per se matters for profitability through the business cycle. It is expected that, like other bank-specific factors, size has a more pronounced effect in times of financial turmoil. The main reasons for such an argument are that larger banks have more resources, allowing them to be sustainable during a longer time period than smaller banks could. At the same time, larger banks have better access to external financing, including government support, which basically makes them "too big to fail." The availability of a bigger capital base and better access to additional financing is crucial for dealing with the severe liquidity problems that occur during periods of financial distress.

In this study, the logarithm of total assets (Log (TA)) will be used as a proxy for the size of banks.

This study's data set covers a period spanning between two major crises: since 2002, the end of high-tech bubble burst lasting 1999-2001, till mortgage-driven one in 2008. The bank-specific data used in this study was obtained from the Bankscope database provided by Bureau van Dijk.

The following classification of countries developed by the FTSE Group is used in this study:

Developed countries: Australia; Austria; Belgium; Canada; Denmark; Finland; France; Germany; Greece; Hong Kong; Ireland; Italy; Japan; Kuwait; Luxembourg; Netherlands; New Zealand; Norway; Portugal; Singapore; Spain; Sweden; Switzerland; United Arab Emirates (UAE); United Kingdom (UK).

Advanced emerging countries: Brazil; Israel; Mexico; South Africa; South Korea; Taiwan.

Secondary emerging countries: Argentina; Chile; China; Colombia; Czech Republic; Egypt; Hungary; India; Indonesia; Malaysia; Morocco; Pakistan; Peru; Philippines; Poland; Russia; Thailand; Turkey.

Frontier countries: Bahrain; Bangladesh; Botswana; Bulgaria; Croatia; Cyprus; Estonia; Jordan; Kenya; Lithuania; Mauritius; Nigeria; Oman; Qatar; Romania; Serbia; Slovakia; Slovenia; Sri Lanka; Tunisia; Vietnam

The following assumptions have been made in order to come up with this categorization (based on FTSE classification), which has been used in the whole time period of study:

- Israel was promoted from advanced emerging countries to developed status in June 2008. Since this event occurred in the middle of 2008, Israel is considered as an advanced emerging economy through the whole time period.

- Hungary and Poland were promoted from secondary emerging markets to advanced emerging countries in June 2008. Following the same logic as with Israel, these countries are kept in the group of secondary emerging countries for the year 2008 as well.

The sample in this study consist of 10,148 banks, with 6,926 banks in developed countries, 556 banks in advanced emerging countries, 2,103 banks in secondary emerging countries, and 563 banks in frontier markets.

The analysis of the performance of banks will be based on an estimation of the model in the following linear form:

$$
\begin{aligned}
& P_{i t}=\alpha_{+} \beta_{1 \text { ETEA }_{i t}+} \beta_{{ }_{2} L L P_{-} N_{I R}{ }_{i t}^{+}} \beta_{{ }_{3} I L G L_{i t}+} \beta_{4{ }_{4} \mathrm{ClR}_{i t}+} \beta_{{ }_{5} \mathrm{SP}_{i t}+} \\
& \text { + } \beta_{6 \text { PTP_TSC }}+\beta_{7 \text { NLTA }}+\beta_{8 H H H_{i t}+} \beta_{9 S_{i t}+} \varphi_{D_{1}+} \vartheta_{D_{2}+u_{i t}}
\end{aligned}
$$

Where $P_{i t}$ denotes profitability of bank $i$ in a year $t$ based on the chosen measure of bank's profitability. Bank's profitability will be measured using nominal rates of return as typical measures of profitability of banks (Antwi and Apau 2015, 77), in particular:

- Return on average assets (ROAA); 
- Return on average equity (ROAE);

and using risk-adjusted rates of return. The prevailing risk-adjusted accounting measurements of performance are return on assets and return on equity (Sharpe ratios / SHROA; SHROE). Sharpe ratios (Stiroh 2004a, 10; Stiroh 2004b, 875; Chiorazzo, Milani, and Salvini 2008, 186) are estimated in the following way:

$\mathrm{SHROA}_{i t}=\mathrm{ROA}_{i t} / \sigma_{i}$

$\mathrm{SHROE}_{i t}=\mathrm{ROE}_{\text {it }} / \sigma_{i}$

Where $\sigma \mathrm{i}$ is the standard deviation over the entire sample period. Higher Sharpe ratios indicate higher profits.

Assessing a bank's performance in this way is simple and transparent. Most important, it considers overall risk exposure.

1. ETEA it - Ratio of Equity to Earning Assets of bank $i$ in a year $t$;

2. LLP_NIRit - Ratio of Loan Loss Provisions to Net Interest Revenue of bank $i$ in a year $t$;

3. ILGLit- Ratio of Impaired Loans to Gross Loans of bank $i$ in a year $t$;

4. CIR it - Cost-to-Income ratio of bank $i$ in a year $t$;

5. $S P_{i t}$ - Spread of bank $i$ in a year $t$;

6. PTP_TSC it - Ratio of Post-tax Profits to Total Share Capital of bank $i$ in a year $t$;

7. NLTA it - Ratio of Net Loans to Total Assets of bank $i$ in a year $t$;

8. HHlit - Herfindahl-Hirschman index of bank $i$ in a year $t$;

9. Sit - Log of total assets as a measure of size of banks of bank $i$ in a year $t$;

10. $D_{1}$ - First-type geographical diversification of bank $i$;

11. $D_{2}$ - Second-type geographical diversification of bank $i$;

Given that this study has more than one dependent variable and the aim of the research is to determine the interaction between variables by defining the level of importance of one variable over another, a multivariate analysis of covariance (MANCOVA) will be used.

In this study, to understand the relative importance of independent variables (covariates, bank-specific factors) for dependent ones through their interaction, Pillai's trace (also called the Pillai-Bartlett trace, $\mathrm{V}$, which is viewed as the most reliable out of multivariate tests, Warne 2014,6) and its level of significance are used. This answers the question: "is each effect significant?" or "is each effect significant for at least one of the dependent variables?" and can take a value from "0" to "1". The larger the Pillai's trace, the more it is significant, and the more the given effect contributes to the model.

In terms of the type of MANCOVA, the Type IV model of MANCOVA was used. This model is specially designed to deal with a dataset in which there are missing data. Absence of some data is common to micro data. Utilization of a method which takes this into consideration is important.

\section{Empirical Findings}

The results of descriptive statistics measured as a mean values with respect to bank-specific characteristics and banks' performance expressed in nominal and risk-adjusted rates of return are reported in Annex 1. Stylized Facts.

It is revealed that even though banks in emerging markets (including frontier economies) outperform those in developed countries based on the nominal rates of return (return on average assets and return on average equity), they substantially underperformed in risk-adjusted measures of profitability (Annex 1. Stylized Facts, Fig. 1-4). This result questions the general idea that emerging markets are more attractive for investments than developed ones.

An economic growth-banks' performance nexus was also explored, the results of which suggested that banks' profitability is generally procyclically driven by economic growth (proxied by the real GDP growth rates, Annex 1. Stylized Facts, Fig. 1-5).

The results of analysis of mean-values for bank-specific factors (Annex 1. Stylized Facts, Fig. 6-14), overall, demonstrate that in terms of capital adequacy, asset quality, earning ability, and management quality with respect to the risk management expertise of financial intermediaries, banks in developed countries clearly outperformed those in emerging and frontier economies. In regard to liquidity, management quality expressed as a cost to income ratio and spread, emerging markets outperformed those in developed countries. However, this should be taken with caution because the cost-to income ratio is likely to be low in emerging markets due to the relatively cheap means of production instead of more efficient cost management.

In order to test study's hypotheses in regard to the importance of micro factors for profitability of banks operating in different economies through time comparative analysis the multivariate results has been performed.

The results of a comparative analysis of Pillai's Trace values with respect to the importance of all bank-specific 
factors for performance of banks in emerging and developed economies are presented further below (Fig. 1 through 11).

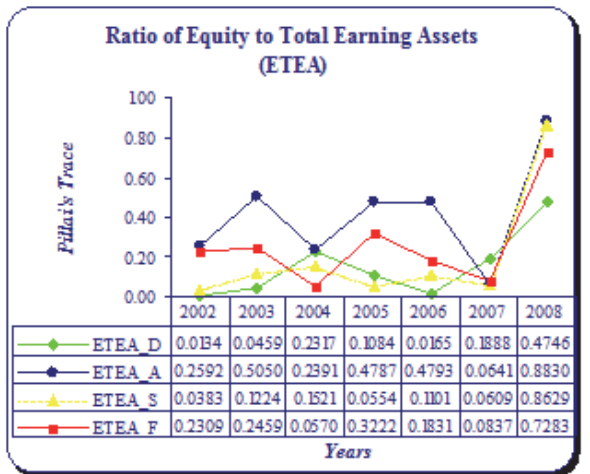

Fig. l. Pillai's trace values for the ETEA ratios of banks which operate in developed (D), advanced emerging (A), secondary emerging $(\mathrm{S})$, and frontier markets $(\mathrm{F})$ from 2002 to 2008.

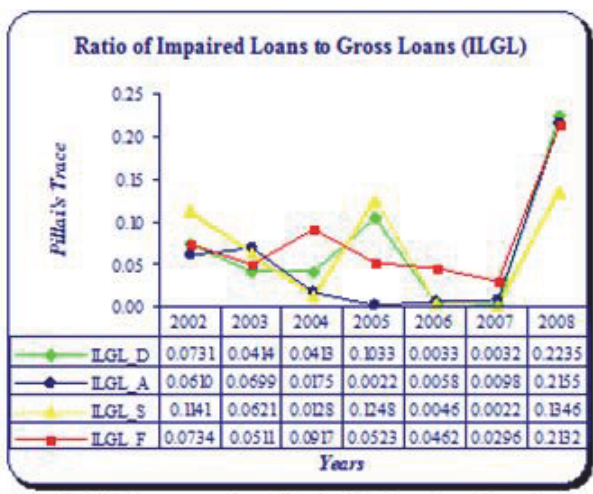

Fig. 3. Pillai's trace values for the ILGL ratios of banks which operate in developed (D), advanced emerging (A), secondary emerging $(S)$, and frontier $(F)$ markets from 2002 to 2008.

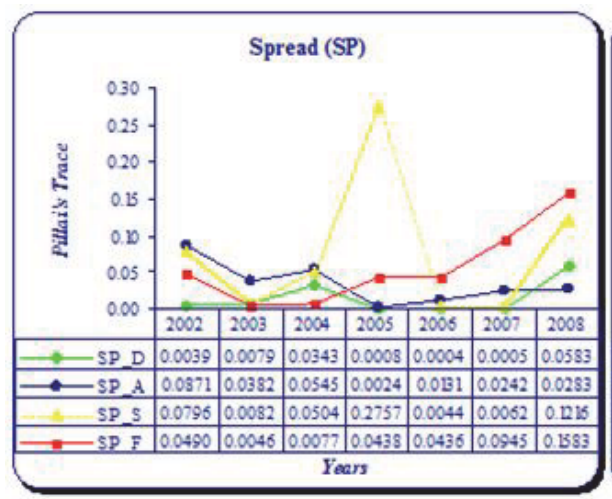

Fig. 5. Pillai's trace values for the spread of banks which operate in developed (D), advanced emerging (A), secondary emerging (S), and frontier (F) markets from 2002 to 2008.

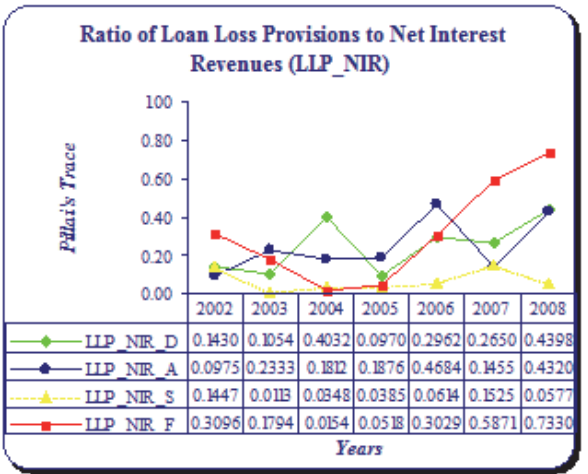

Fig. 2. Pillai's trace values for the LLP_NIR ratios of banks which operate in developed (D), advanced emerging (A), secondary emerging (S), and frontier $(F)$ markets over from 2002 to 2008.

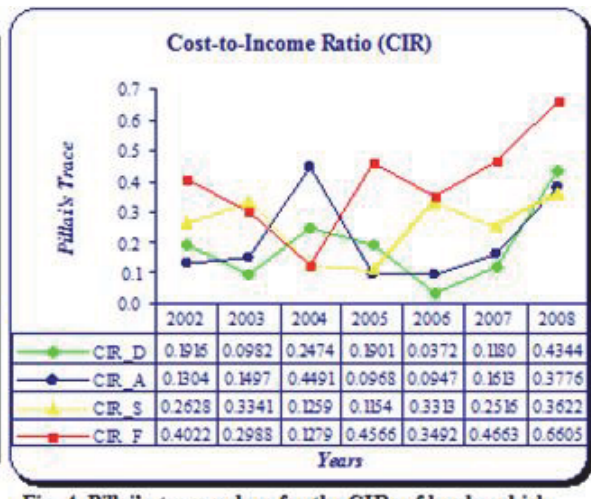

Fig. 4. Pillai's trace values for the CIRs of banks which operate in developed (D), advanced emerging (A), secondary emerging $(\mathrm{S})$, and frontier $(\mathrm{F})$ markets from 2002 to 2008.

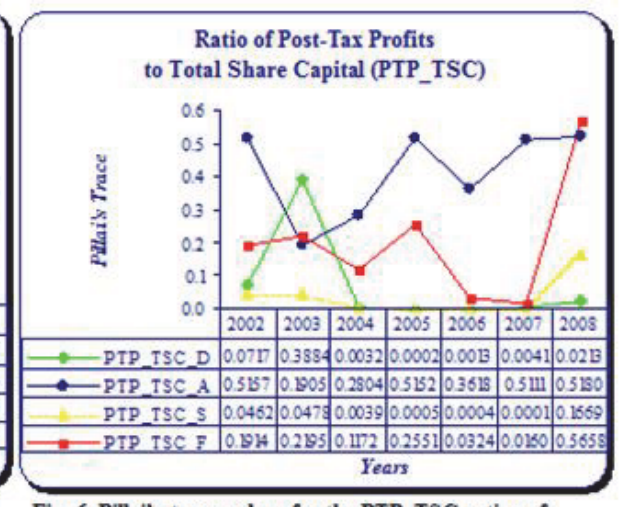

Fig. 6. Pillai's trace values for the PTP_TSC ratios of banks which operate in developed (D), advanced emerging $(A)$, secondary emerging $(S)$, and frontier $(F)$ markets from 2002 to 2008. 


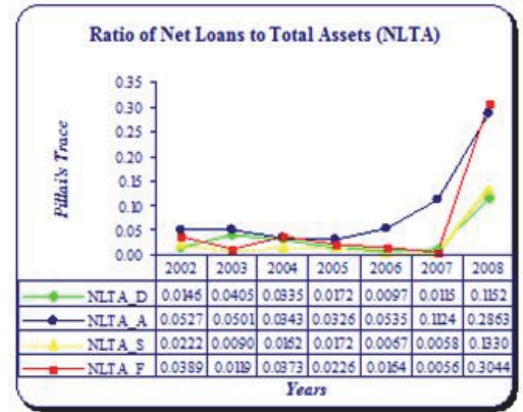

Fig. 7. Pillai's trace values for the NLTA ratios of banks which operate in developed (D), advanced emerging (A), secondary emerging $(\mathrm{S})$, and frontier $(\mathrm{F})$ markets from 2002 to 2008.

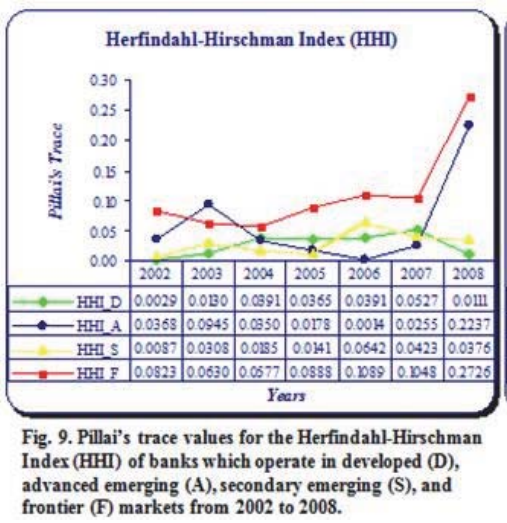

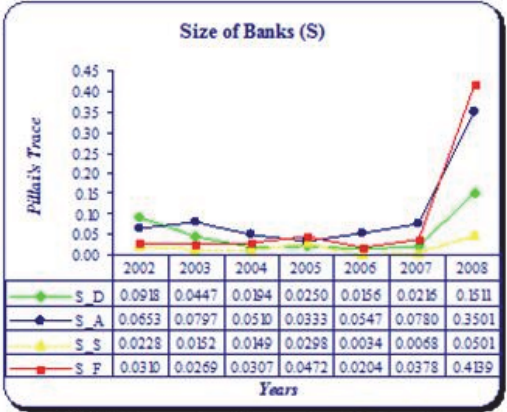

Fig. 8. Pillai's trace values for the size of banks which operate in developed (D), advanced emerging (A), secondary emerging $(S)$, and frontier $(F)$ markets from 2002 to 2008 .

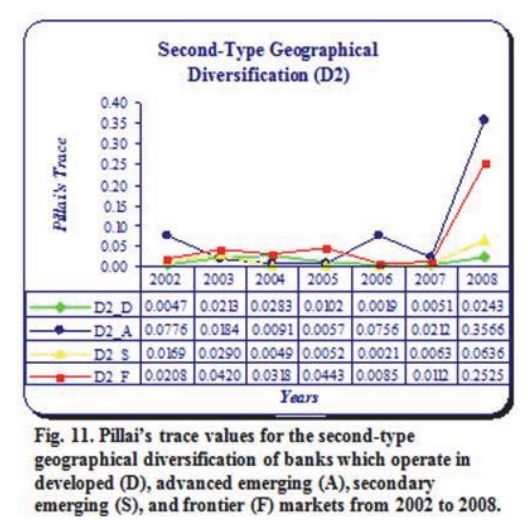

The outcomes of Pillai's trace values are supportive of the main theoretical proposition of this reseach and demonstrate that the relative importance of all bank-specific factors goes countercyclically with the business cycle and during the times of financial distress the importance of all-bank-specific factors increases sharply.

\section{Conclusion}

This study empirically explored the relative importance of bank-specific factors on the profitability of banks operating in developed, advanced emerging, secondary emerging and frontier markets (based on the FTSE Group's classification) from 2002 to 2008.

The empirical findings, overall, support the theoretical proposition that all internal factors matter more in periods of financial distress than in recoveries. This confirms an intuition that a divergence of expectations of all market participants with respect to the overall economic situation, an escalation in agency problems and increase in default rates of the real sector in downturns make banking organization to strengthen internal controls and improve management practices to 
mitigate overall risk exposure and ensure stability in the periods of economic recession.

With respect to policy implications, the results of this work, overall, suggest that the central issues for regulators to look at are the level of banks' capital base and liquidity. It means that regulatory requirements in regard to capital adequacy should be strengthened but not overnight, because the amount of capital held by banks cannot be increased that quickly.

Further, one has to be realistic and accept that banks are service organizations. The amount of financial resources they have is related to the amount of financial resources they get from real sector. If the real sector has nothing to share with banks, this will negatively affect the banking sector. The danger of a real aggregate liquidity shortage for the banking sector lies in the inability of banks to satisfy all requests from companies in trouble while at the same time satisfying requests to withdraw deposits. Depositors are also representatives of the real sector and have the same problems as corporate clients, but in terms of scale, they are less.

Thus, it is not recommended imposing tighter requirements neither for the level of capital nor for the amount and quality of banks' liquid assets during a period of economic crisis, since this will not help diminish ongoing problems. Instead, these requirements could be introduced once the period of any financial turmoil is over which will allow to mitigate the negative consequences of further crises.

\section{References}

Antwi, F. and Apau, E. (2015). "Financial Performance of Rural and Community Banks (RCBs) in Ghana." The International Journal of Business \& Management 3(2): 76-85.

Balteş, N. and Rodean, M. (2014). "Study regarding the financial stability of commercial banks listed on Bucharest Stock Exchange of CAMELS rating outlook." Journal of International Studies 7(3): 133-143.

BankScope Database, Bureau van Dijk (2009).

Beckmann, R. (2007) "Profitability of Western European Banking Systems: Panel Evidence on Structural and Cyclical Determinants." The Deutsche Bundesbank Discussion Paper Series 2: Banking and Financial Studies, No 17/2007.

Boot, A. W. A. and A. Schmeits (2000). "Market Discipline and Incentive Problems in Conglomerate Firms with Applications to Banking." Journal of Financial Intermediation 9(3): 240-273.

Bronfenbrenner, M. (1945). "Some Fundamentals in Liquidity Theory." The Quarterly Journal of Economics 59(3): 405-426.

Chiorazzo, V., C. Milani, and F. Salvini (2008). "Income Diversification and Bank Performance: Evidence from Italian Banks." Journal of Financial Services Research 33(3): 181-203.

Dages, B. G., L. Goldberg, and D. Kinney (2000). "Foreign and Domestic Bank Participation in Emerging Markets: Lessons from Mexico and Argentina." Economic Policy Review 6(3): 17-36.

Demirgüç-Kunt, A. and H. Huizinga (1999). "Determinants of commercial bank interest margins and profitability: Some international evidence." The World Bank Economic Review 13.

Deng, S. and E. Elyasiani (2008). "Geographic Diversification, Bank Holding Company Value, and Risk." Journal of Money, Credit and Banking (Blackwell) 40(6): 1217-1238.

Diamond, D. W. and R. G. Rajan (2000). "A Theory of Bank Capital." The Journal of Finance 55(6): 2431-2465.

Diamond, D. W. and R. G. Rajan (2001). "Liquidity Risk, Liquidity Creation, and Financial Fragility: A Theory of Banking." The Journal of Political Economy 109(2): 287-327.

Diamond, D. W. and R. G. Rajan (2005). "Liquidity Shortages and Banking Crises." The Journal of Finance 60(2): 615-647.

Duygun-Fethi, M. and F. Pasiouras (2009) "Assessing Bank Performance with Operational Research and Artificial Intelligence Techniques: A Survey." University of Bath School of Management Working Paper 2009.02: 1-65. Available online at http://www. bath.ac.uk/management/ research/pdf/2009-02.pdf.

Federal Register (1997), 62 (3): p.755

The FTSE Country Consultation Results (2004, March). FTSE The Independent Global Index Company.

The FTSE Country Classification (2004, September, Update). FTSE The Independent Global Index Company.

The FTSE Country Classification (2005, September, Update). FTSE The Independent Global Index Company.

The FTSE Country Classification. (2007, September, Update). FTSE The Independent Global Index Company.

The FTSE Country Classification. (2009, September, Update). FTSE The Independent Global Index Company.

Fries, S., D. Neven, and P. Seabright (2002). "Bank performance in transition economies." William Davidson Institute Working Paper 505,30

Goddard, J. A., P. Molyneux, and J.O.S. Wilson (2004). "The Profitability of European Banks: A Cross-Sectional and Dynamic Panel Analysis." The Manchester School 72.

Hunjak, T. and D. Jakovčević (2001). AHP Based Model for Bank Performance Evaluation and Rating. 6th ISAHP, Berne, Switzerland.

Johnson, S., J. McMillan, and C. Woodruff (2002). "Property Rights and Finance." American Economic Review 92(5): 1335-1356.

Kotrozo, J. E. and S. Choi (2006). "Diversification, Bank Risk and Performance: A Cross-Country Comparison." SSRN eLibrary. Available online at http://ssrn.com/paper=1013430.

La Porta, R., F. Lopez-de-Silanes, A. Shleifer, and R. Vishny (1997). "Legal Determinants of Extemal Finance." Journal of Finance 52(3): 
$1131-1150$.

Lewellen, W. G. (1971). "A Pure Financial Rationale for the Conglomerate Merger." Journal of Finance 26: 521-537.

Stiroh, K. J. (2004a). "Do Community Banks Benefit from Diversification?" Journal of Financial Services Research 25(2/3): $135-160$.

Stiroh, K. J. (2004b). "Diversification in Banking: Is Noninterest Income the Answer?" Journal of Money, Credit and Banking 36(5): 853882.

Webb, D. C. (2000). "The Impact of Liquidity Constraints on Bank Lending Policy." The Economic Journal 110(460): 69-91.

Warne, R.T. (2014). "A Primer on Multivariate Analysis of Variance (MANOVA) for Behavioral Scientists." Practical Assessment, Research \& Evaluation 19 (17): 2-10.

Annex 1. Stylized Facts
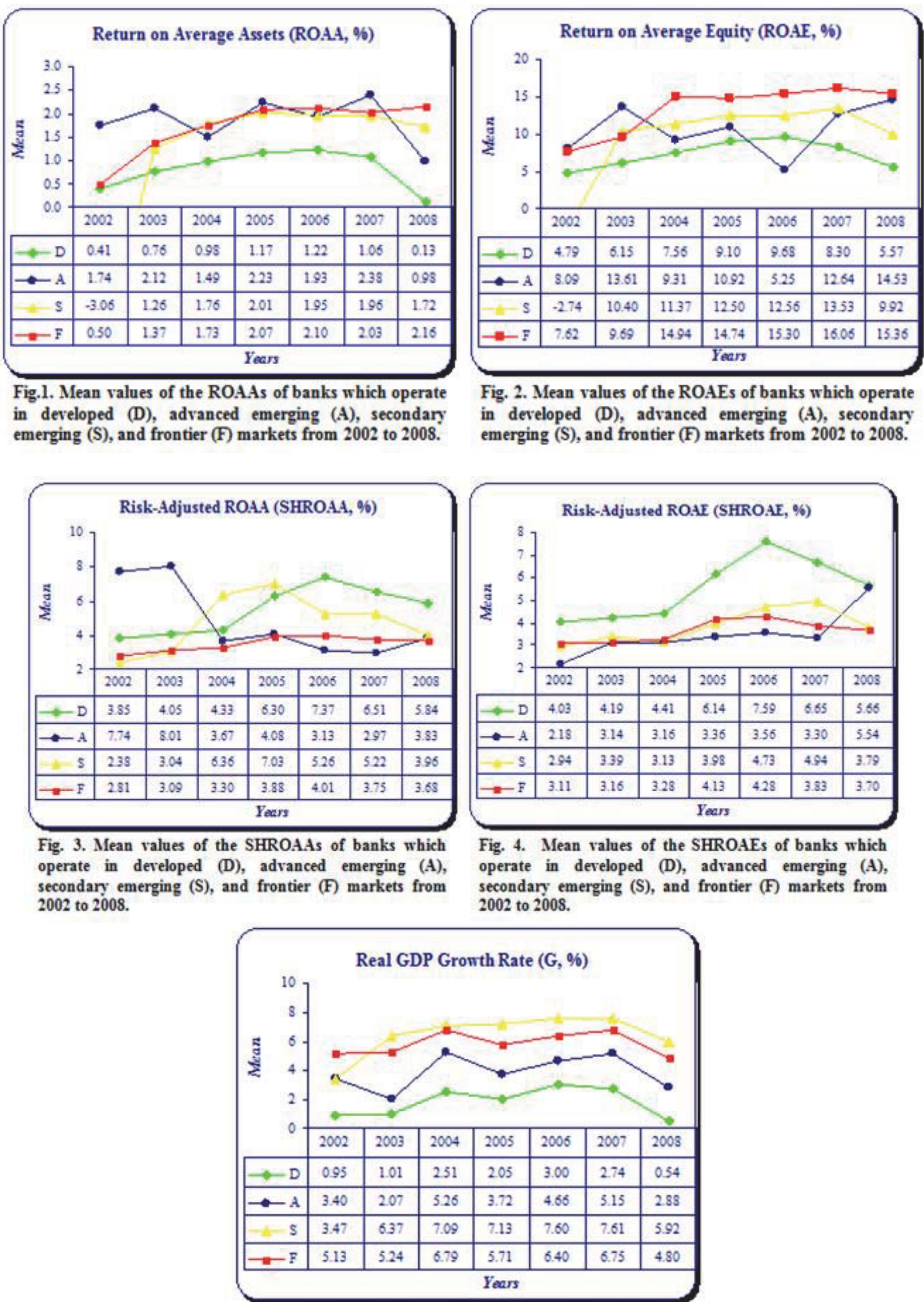

Fig. 5. Mean values of the real GDP growth rates in developed (D), advanced emerging (A), secondary emerging (S), and frontier (F) markets from 2002 to
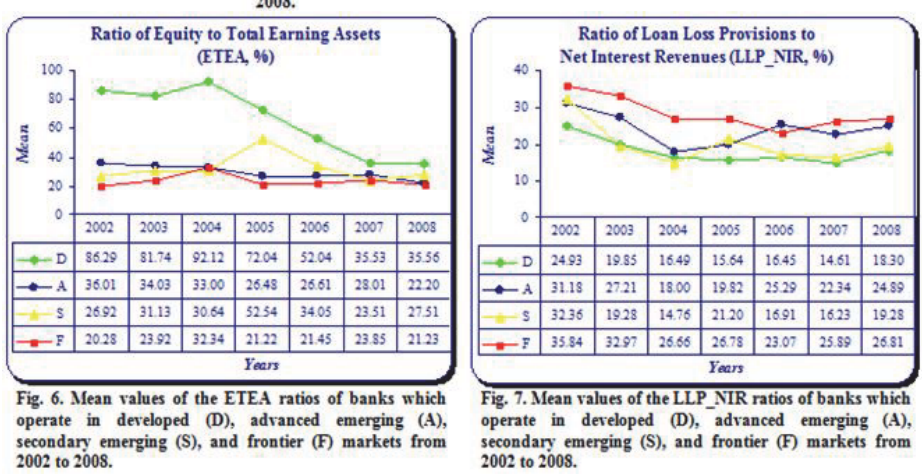

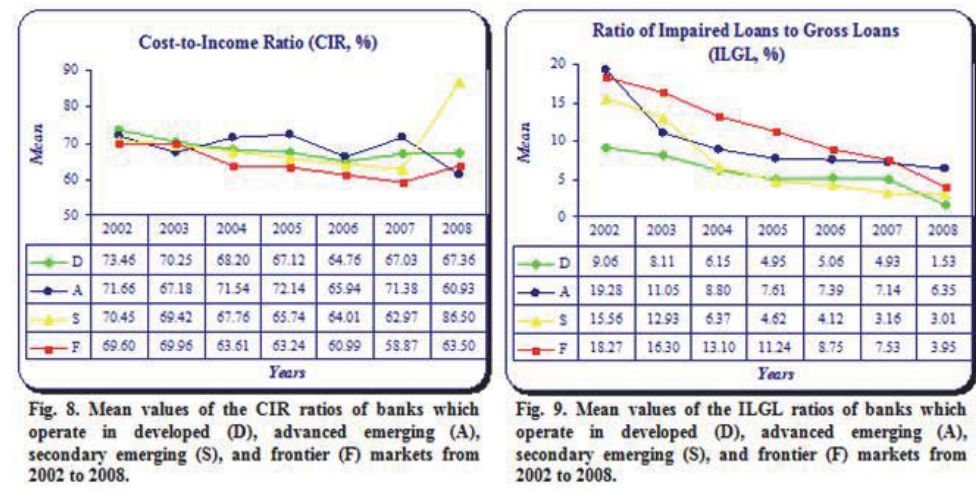

Fig. 9. Mean values of the ILGL ratios of banks which Fig. 9. Mean values of the ILGL ratios of banks which
operate in developed (D), advanced emerging (A), operate in developed (D), advanced emerging (A), 2002 to 2008. secondary emerging (S), and frontier (F) markets from 2002 to 2008.

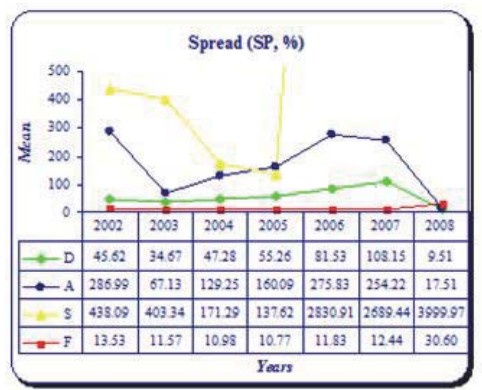

Fig. 10. Mean values of the spreads of banks which operate in developed (D), advanced emerging (A), secondary emerging $(S)$, and frontier $(F)$ markets from 2002 to 2008.

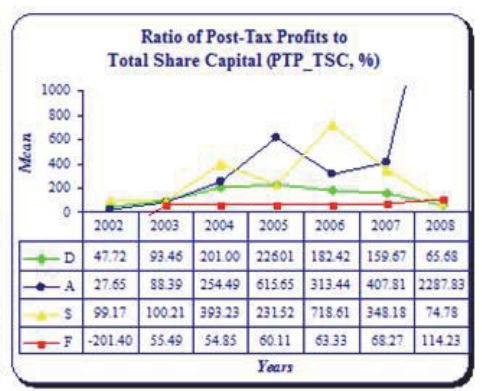

Fig. 11. Mean values of the PTP_TSC ratios of banks which operate in dereloped (D), advanced emerging (A), secondary emerging ( $S$ ), and frontier $(F)$ markets from 2002 to 2008.
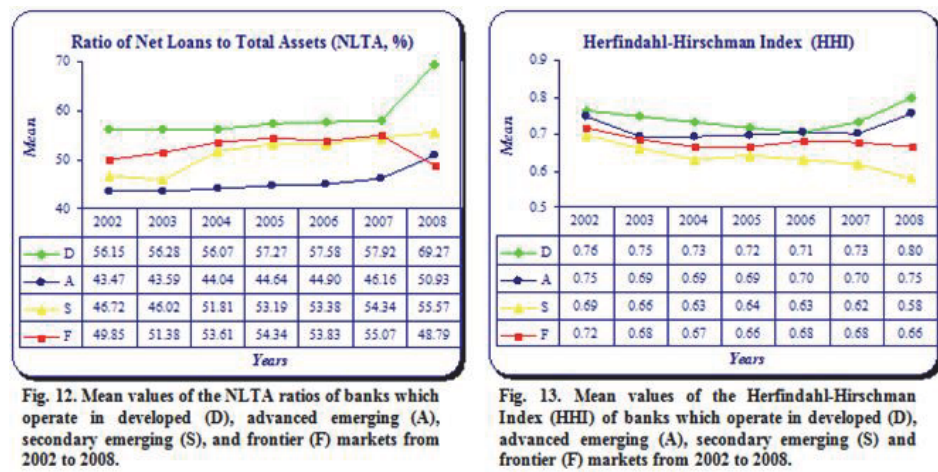

Fig. 13. Mean values of the Herfindahl-Hirschman Index (HHI) of banks which operate in dereloped (D), advanced emerging (A), secondary emerging (S) and frontier $(\mathrm{F})$ markets from 2002 to 2008.

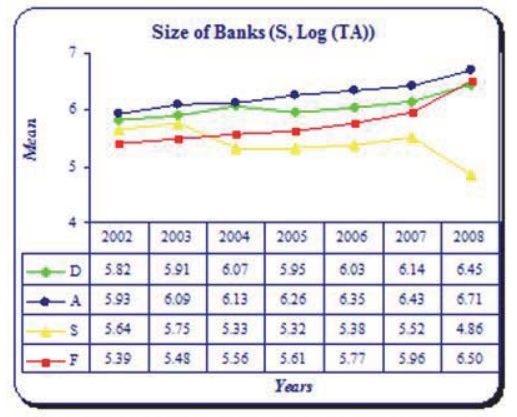

Fig. 14. Mean values of size $(\log (\mathrm{TA}))$ of banks which operate in developed (D), advanced emerging (A), secondary emerging $(S)$, and frontier $(F)$ markets from 2002 to 2008. 